This item was submitted to Loughborough's Research Repository by the author.

Items in Figshare are protected by copyright, with all rights reserved, unless otherwise indicated.

\title{
A succession of dialogues: François-Marie Luzel and his contribution to the Breton folktale
}

PLEASE CITE THE PUBLISHED VERSION

https://doi.org/10.1386/btwo_00011_1

PUBLISHER

Intellect

VERSION

AM (Accepted Manuscript)

PUBLISHER STATEMENT

This paper was accepted for publication in the journal Book 2.0 and the definitive published version is available at https://doi.org/10.1386/btwo_00011_1.

LICENCE

CC BY-NC-ND 4.0

\section{REPOSITORY RECORD}

Wilson, Michael. 2019. "A Succession of Dialogues: François-marie Luzel and His Contribution to the Breton Folktale”. figshare. https://hdl.handle.net/2134/38325. 


\title{
A Succession of Dialogues: François-Marie Luzel and his contribution to the Breton Folktale
}

\begin{abstract}
François-Marie Luzel (1821-1895) was one of the most significant French folklorists of his day and champion of Breton culture. He mainly collected folktales in his native Lower Brittany and published prolifically, including three volumes in the monumental Contes populaires series, published by Maisonneuve and Charles Leclerc in 1887.
\end{abstract}

On the one hand, Luzel was a man of his time, adopting the philosophies and approaches of his fellow folklorists and antiquarians. However, many of his methods, in particular his insistence on authenticity and fidelity to the spoken word, and his realization that traditional cultures are enriched and preserved not through cultural isolation, but by interaction with other cultures, seem out of step with the attitudes of many of his contemporaries and rather seem to anticipate twentieth century developments in folktale collecting practice. Furthermore, Luzel often courted controversy and regularly came into conflict with many of his colleagues in the Breton cultural and political establishment around his insistence on publishing in French and his attitude towards the literary 'Unified Breton' and the associated debates around what constituted an authentic Breton culture. 
This article will place Luzel in his historical context and explore his approach to collecting and publishing his folktales and the controversies he courted. It is followed by a companion piece - a new translation of one of Luzel's tales 'Jannic aux deux sous' ('Tuppenny Jack'*) - a Breton variant of 'The Frog Prince'.

\section{Keywords}

François-Marie Luzel

Breton

Folk tales

Translation

Collecting

François-Marie $\operatorname{Luzel}^{1}(1821-1895)$ was arguably one of the most significant French folklorists of his day and champion of Breton culture, where his influence was substantial in laying the groundwork for the following generation of Breton folklorists, such as Paul Sébillot and Anatole le Braz. His legacy largely rests in the collections of folktales which he made in his native Lower Brittany and which he began publishing in 1870, culminating the three volumes he produced for the monumental Contes populaires series, published by Maisonneuve and Charles Leclerc in 1887. This paper explores Luzel's developing practice as a folklorist,

\footnotetext{
${ }^{1}$ Luzel was also known by his Breton name of Fañch an Uhel and occasionally by Frances Maryyear Uhel, as well as a host of other pseudonyms.
} 
collector, translator, editor and promoter of Breton culture and language at a time of a rapidly developing understanding of the place of the folktale within a community's cultural tradition. Rather than seeing Luzel's work as conforming to a fixed set of beliefs, it is best to see his work as a developing practice that responded to a series of 'dialogues' between himself, his fellow folklorists, the Breton establishment and, most of all, the storytellers who shared their tales with him.

Luzel was born in the manor of Keramborgne, the family home, in the commune of Plouaret, the eldest son in a family of ten children. His family were Breton speakers of farming stock with Republican leanings who had come into ownership of the manor in recognition of his grandfather's service in the Revolution. In relation to their neighbours they were not a poor family, but neither were they particularly wealthy. It was a life not without its precarity, but one that was firmly embedded within the local community, its landscape and customs. Luzel himself recalled as a child how the family home would regularly host veillées, social gatherings where stories were told and news exchanged during the dark winter months, not unlike the ceilidhs that have been well documented in rural Ireland and Scotland ${ }^{2}$. Family members, farm workers and other members of the local community would attend the veillées at Keramborgne, but what was particularly anticipated were visits from the travelling mendiant(e)s (beggars) who would bring fresh news and new stories to the commune. The most successful of these storytelling events were seemingly

\footnotetext{
${ }^{2}$ See, for example, amongst others, Zimmerman (2001) for an exhaustive description of Irish storytelling traditions and Delargy (1945) for a comparison between Scottish and Irish traditions.
} 
a mix of 'home and away', echoing Walter Benjamin's two types of storyteller: 'the resident tiller of the soil and (...) the trading mariner' $(1977,386)$.

There is no doubt that Luzel was heavily influenced by his experiences at the veillées, but of equal significance was his relationship with his uncle, Julien-Marie Le Huërou, a teacher at the Collège royale de Rennes, which Luzel himself attended from 1835 for his secondary education. Le Huërou was a keen scholar of Breton culture and it was through him that Luzel was first introduced to his circle of like-minded friends. It was also through his uncle's influence that Luzel first discovered his own aptitude for scholarship.

Le Huërou had a particular approach to the study of Breton culture that was adopted by Luzel, namely an interest in comparing it with other European cultures and languages and thus placing it within a much wider cultural context. This is in contrast to other Breton scholars of the time who pursued a more separatist or nationalist agenda that sought to establish Breton as a 'pure' culture in its own right without outside influence. Likewise Le Huërou rejected many of the cultural stereotypes, such as druidism, that were being promoted by many of his contemporaries in the early Breton folklore movement and was highly critical of figures such as the aristocratically titled Théodore Hersart de La Villemarqué and his publication of the Barzaz Breiz, a collection of traditional Breton songs in 1839 (de La Villemarqué 1999). After his uncle's suicide in 1843, following a failed application for promotion, Luzel took on the job of completing his unfinished work, a useful apprenticeship in folklore scholarship that also involved embedding his uncle's own philosophical and political approach into his 
own emerging practice. In particular, in a move that was to dominate his professional life (and also his reputation after his death), Luzel took up the fight against de La Villemarqué. In 1872, with the encouragement of Ernest Renan (1823-1892), Head Librarian at the Bibilothèque Nationale, who he had befriended in 1857, at the Congress of the Breton Association in Saint Brieuc, Luzel condemned Barzaz Breiz as a fake and de La Villemarqué as a fraud. Luzel accused La Villemarqué of completely inventing the songs within the book, in the same way that James MacPherson had forged the successful Poems of Ossian in the 1760s and Iolo Morgannwg (Edward Williams) had published 'discovered' Welsh bardic poems in the late eighteenth and early nineteenth centuries.

Suspicion had already fallen upon the veracity of de La Villemarqués work, not least because of the lack of variants of the published songs in Barzaz Breiz and his use of 'unified Breton'. This was a constructed, literary form of Breton, free of local variation and showing no influence from other languages, whereas Luzel knew that the Breton spoken by the rural populations was filled with outside influences, most notably French. In 1867 de La Villemarqué published the third edition of Barzaz Breiz and Luzel came under some pressure to publish his own collection of Breton songs, Le Gwerziou, which when placed alongside de La Villemarqué's work, would expose the forgery. As Luzel worked on the project he became increasingly convinced of de La Villemarqués dishonesty, writing to Renan in September 1867: 'The more my work progresses, the more convinced I am that M. de La Villemarqué has played the role of Macpherson for us and that he has been deceiving us for more than a quarter of a century' (quoted in Morvan, 1999, 168). 
Whilst de La Villemarqué's romantic nationalism had long been dismissed by many within the wider scholarly community, Barzaz Breiz had been commercially successful and both it and the young antiquarian had been adopted by the Breton cultural establishment, against which Luzel was now firmly setting himself. De La Villemarqué had established his reputation as a leading scholar of Breton language and literature and Luzel's public condemnation of him was not universally welcomed. Luzel had always been something of an establishment outsider, in spite of the undoubted quality of his scholarship, in part due to his being largely self-educated and unqualified (he never progressed beyond his baccalaureat), and there now followed a period where he found it difficult to find a publisher for his work, placing even more financial pressure on him.

The argument itself was much bigger than the two individuals involved and, in spite of occasional flare-ups over the following years, both Luzel and de La Villemarqué maintained a respectable, if slightly cool, professional relationship. They only became fully reconciled in 1890, when de La Villemarqué himself presented Luzel with the Chevalier of the Légion d'honneur, an indication that he had finally been accepted by the establishment. However, this was really a debate between two opposing ideological positions (and one that continued well into the next century when, according to Sharif Gemie, Barzaz Breiz was still revered by Breton cultural nationalists $(2007,47))$. Each had his supporters and detractors, and Luzel and de La Villemarqué symbolised perfectly the tensions between them: de La Villemarqué was from an affluent, pro-Royalist, conservative, pro-Catholic family, whilst Luzel was from Republican farming 
stock with anti-clerical instincts and spent most of his life struggling to meet his financial obligations. De La Villemarqué was also a Romantic Nationalist, although not a separatist. He was of the belief that Breton represented the true and original French culture and offered the country a route back to a purer, and more Catholic, national way of life. Luzel, on the other hand, was a scientific rationalist and a strong supporter of Breton culture (he lobbied hard and unsuccessfuly for the inclusion of Breton in the schools' curriculum). He was also a philologist and felt a deep affiliation for the working poor amongst whom he lived. Whilst his goal may have been to do, through his story-collecting, for his native Brittany, what the Brothers Grimm did for Germany, he understood the stories he collected within the wider context of the treasury of European folktales. He felt that earlier collections, with their heavily edited, composite versions, which brought together multiple variants into an official, 'correct' form, couched in romantic and lyrical langauge, failed to capture the authentic language of the people and their concerns. Luzel knew the lives of the people who told him their stories and he instinctively knew that these stories, embedded with a hatred of the old seigneurial system and with a preference for the servant over the master, reflected the aspirations and daily struggles of his neighbours, rather than being simply some half-forgotten cultural memory from the distant past.

At the root of Luzel's attitudes to the material he collected, and key to understanding the texts of the stories, are his experiences as a collector and the methods he employed. Sometimes these were due to pragmatic choices, but they shaped his research and made him, interestingly, at one moment a man very 
much of his time, a product of his context, whilst the next moment seeming to be very much ahead of his time, gaining insights that did not become widely accepted until much later.

The first thing to remember here is that Luzel's stories were all collected in person, although not always by himself. Luzel's sister, Perrine, was a regular (if unacknowledged) collaborator and regularly contributed stories that she had herself collected at veillées ${ }^{3}$. Luzel, however, did not rely on correspondents in the way that other nineteenth century folklorists often did - as a philologist and promoter of Breton language and culture, it was critical to him to record accurately the language used by his storytellers, something that could only be achieved through being present at the storytelling event itself. Luzel's adherence to following a 'scientific' approach to folktale study demanded no less.

The second thing worth noting here is that Luzel's collecting took place in three main contexts: at veillées at which either he or Perrine were in attendance as either guests or hosts; at personal interviews where storytellers came to visit him; at personal interviews where he sought out the storyteller and visited them. Luzel was a regular attendee at veillées all his life, which gave him knowledge of, and access to, the most prolific storytellers in the area around Plouaret. However, as his interest in folktales became more widely known, storytellers would seek him out, as a known and respected member of the community. Luzel collected multiple tales from some storytellers and his two most prolific

\footnotetext{
${ }^{3}$ Most notably in Contes du Boulanger, a collection of stories collected during evening storytelling sessions held at a bakehouse in Morlaix during the winter of 1888-9.
} 
informants were March'haid Fulup (Marguerite Philippe) from the village of Pluzunet and Barba Tassel from Plouaret. Philippe, who was in demand as a singer and known for her formidable memory, made her living from spinning and acting as a professional pilgrim, which involved travelling to holy shrines for others in order to seek the intervention of the saint on their behalf. Tassel was a mendiante (beggarwoman) who also delivered the mail. Between them Philippe and Tassel furnished Luzel with stories throughout the entirety of his collecting life and provided him with enough tales to allow him to make comparative studies of variants. Philippe in particular would often visit Luzel to provide him with new stories, in exchange for which she received a Christmas box of ten francs and food and accommodation whenever she needed it.

Less commonly, Luzel would collect stories from tellers in their own homes. This collecting seems to have taken place alongside his conducting of other business that took him away from his immediate neighbourhood, although he rarely seemed to have ventured very far. This was as much driven by financial constraints as anything else. Whereas other, more financially independent folktale collectors of the time could afford to travel to remote places (where it was assumed a more authentic folk culture could be found), Luzel needed to apply for funding or patronage to support such ventures (something at which he was rarely successful) and so needed to source his material locally, or in connection with his other professional obligations. Fortunately for Luzel he found a rich vein of material in his local neighbourhood and this gives his collection a unique flavour. 
On one occasion, Luzel did indeed embark further afield on a collecting field trip, into the Cournaille, an interior mountainious area of Brittany, the detail of which he records in his 'Deuxième rapport' (Luzel, 1995a, 125-31. Armed with an optimism that was borne of the scholarly assumptions of the time and the richness of the material he knew existed in the villages and towns around Plouaret, he fully expected to uncover a treasure trove of narrative in the remote and isolated communities around the mountains of Avez. However, he was to be disappointed. Lack of funds forced him to suffer the discomforts and indignities of travelling on foot and, to add insult to injury, his collecting was far from the success he had hoped for. He found his informants sometimes surly and unforthcoming compared to the storytellers he knew from his home, and he considered their stories inferior to the material he had already collected.

This is perhaps not surprising, given the familiar figure he cut around Plouaret and the neighbouring communities, and the respect he commanded there, but the failure of the field trip led Luzel to a remarkable conclusion, the significance of which Luzel may not have realized at the time. Contrary to popular opinion of the time, Luzel surmised that it was not actually in the remote areas of the country that rich folkloric traditions survived, but in the better connected communities that had trading relationships with a much larger and more distant set of cities, towns and villages. Luzel concluded that remoteness did not in itself protect a community's folk culture, but in fact such cultural traditions were nourished and enhanced by contact and engagement with other cultures. The towns and villages with easy access to the coast and ports with their overseas trade in particular benefitted from this intercultural traffic, which explained why 
many of the stories that Luzel was collecting had variants across other European folktale traditions. The inevitable consequence of Luzel's observations was that folk traditions are not simply the archaeological ruins of a distant intangible heritage, but living cultural forces that live as much in the present day, reflecting the struggles and aspirations of contemporary communities.

We should, however, be wary of dressing Luzel in twentieth century clothes. He was still very much a man of his times and he organized many of his collections according to the principles of Solar or Comparative Mythology, as espoused by Max Müller4, an approach that was already being increasingly challenged by the cultural anthroplogists, such as Andrew Lang5. In his introduction to Contes populaires de Basse-Bretagne, Luzel manages to bridge the two camps with no little skill and diplomacy (1887, II-III), praising and criticizing in equal measure, and espousing an approach he called 'mythological eclecticism' (1887, VII) that took on the best of both Müller's monogenetic, philological system and Lang's polygenic and Darwinian thinking.

Luzel believed that an approach to the study of folktale needed to be built upon sound analytical principles. It was only through the collection of multiple

\footnotetext{
${ }^{4}$ Friedrich Max Müller (1823-190o) was a Sanskrit scholar and philologist,. He was the first holder of the posts of Professor of Comparative Philology at Oxford University, and was also a pioneer in the fields of Vedic studies, comparative philosophy, comparative mythology and comparative religion. See: Abraham and Hancock The Gifford Lectures Newsletter [online] https://www.giffordlectures.org/lecturers/friedrich-max-m\%C3\%BCller [accessed 27 May 2019]

${ }^{5}$ Andrew Lang (1844-1912 ) was a Scottish poet, novelist, literary critic, historian, classical scholar and anthropologist. Now, probably best known for his collections of fairy tales, especially The Blue Fairy Book (1889) and subsequent collections of 'coloured' collections of fairy tales.
} 
variants of the same story that the folklorist could reduce them down to a set of shared symbols and thus create one single, authoritative meaning. This approach, which seems very reductive to us today, was all about the application of scientific principles, allowing folktales to be studied in the same way as, say, botany and thus affording folklore study a scholarly respectability that it was otherwise denied. Catherine Velay-Vallantin remarks that, "1870, the date of the publication of the first volume of François-Marie Luzel's Contes Bretons, marks the rapid expansion of collections executed in the spirit of science" $(1992,14)$. Furthermore, Luzel's enduring commitment to the idea that folk culture was in constant danger of disappearing altogether is reflected in his closing, passionate statement in his introduction to the first volume of Contes populaires:

This is, in effect, the literature of the unschooled and the unfortunate, who know how to neither read nor write (...) and (...) we must (...) love it, respect it and hasten to collect it, at the very moment when it is in danger of disappearing forever.

(1887, XIX-XX)

Such a statement places Luzel firmly within his own time and, in spite of the startling modernity of certain aspects of his practice, he remains very much the nineteenth century folklorist that he was. Luzel derived meaning from the similarities between variant texts of the story, not the differences, as a modern performance-led folklorist may do. His understanding remains that of folklore as primarily chronological and archaeological. 
The same blend of conservatism and radicalism can be seen in Luzel's approach to the preparation and publication of his material. Or perhaps one should say 'approaches', because he experimented with different forms of dissemination. The fact that Luzel sometimes agonized over how he might present the stories to a reading public suggests that he considered publication as being an integral part of the scholarly process, subject to the same considerations and rigours as the collecting of material itself, rather than simply an (often commercially-driven) adjunct to it.

As a starting point we should bear in mind Luzel's practice of collecting multiple variants of the same tale and his insistence on capturing the precise words used by his informants. The latter immediately presented Luzel with a problem, as his informants spoke not in Uniform Breton, but in a patricular dialect of Breton that was often unintelligible to Breton speakers in other parts of Brittany. In addition, Luzel's commitment to Brittany manifested itself in his desire to publish in French, in contrast to many of his contemporaries, as a way of gaining a wider readership and thus greater respectability for Breton culture. In fact, Luzel published his stories in French, Breton and often in bilingual editions. His first volume, Contes Bretons (1870) is a case in point, which contains only six stories, but they appear in either French alone, or in both French and Breton versions alongside each other. This appears to be an experiment in translation and Luzel is ultimately using the translation process as a way of thinking about translation practice. 
In the first instance, though. we need to consider the status of the Breton that he was translating from. Françoise Morvan (Luzel, 1995a, 180-81) explains that Luzel would first compile a text in Breton from his fieldwork notes. This in itself was a complex task, given that he was dealing with a spoken language which existed in multiple dialects and without any literary texts to guide him in terms of spelling and grammar. Of course, Luzel could have resorted to the artificial, literary Unified Breton, but he wanted to render the stories in a kind of Breton that reflected the everyday speech in which they were told. So, already Luzel was making compromises in terms of creating his own form of the language that was a mixture of three different Breton dialects, in order to render something that was legible to the Breton reader, whilst retaining the flavor of its orality. So, in a way, even the Breton versions that Luzel published were translations of texts constructed from written notes of an oral performance.

From this Breton text, Luzel would then make a literal French translation, which he would then rework in order to improve its style and make clarifications so that it became a more readable text, without needlessly elaborating. Finally, with reference to the French translation, he would then return to the Breton text, editing it further into something suitable for publication.

In Contes Bretons Luzel is still developing his editorial practice and adopts three distinctive translational approaches and invites the reader to write it to him with feedback. Three of the stories appear as relatively free translations from Breton into French. Two of them appear in both Breton with a fairly close French 
translation alongside. The last story also appears bilingually, but this time the translation is a literal one.

The process described by Morvan sounds rather convoluted and interventionist, but Luzel would have seen it as part of his responsibility as a folklorist and his editorial hand is much lighter than many of his contemporaries. Nevertheless, the French versions he published would have been edited translations of translations of texts constructed from written notes of an oral performance. Moreover, the English text of 'Tuppenny Jack', which accompanies this short essay is no more than a translation of a translation of a translation of a text constructed from written notes of an oral performance! Given Luzel's emphasis on the accuracy of capturing what was actually said to him by his storytellers, we seem to be getting pretty far away from anything that might be called authentic.

However, this is only a problem if we consider the stories as told to Luzel by Marguerite Philippe, Barba Tassel and others authentic 'urtexts' that must be treated as holy writ. If, however, we concur with Walter Benjamin that any telling of a story is, in fact, a retelling, then we can begin to understand each text as merely representing a single moment in a continuing cycle of storytelling performances in which the story is reinvented afresh each time by the teller. Luzel's storytellers were themselves simply reinventing stories that they had heard from a long line of tellers before them. One version of the story, therefore, carries no greater authority than another and each version arguably tells us more about the teller and their audience, than it does about the story itself. In this sense, Luzel's process of preparing a text for publication can be understood 
as a series of retellings, albeit ones in which he seeks to honour the person who told him the story and reflect the tale as he heard it. In the same spirit of performance and retelling, I offer you at the end of this essay, 'Tuppeny Jack'.

Let me finish, however, with a note on Luzel's legacy and a sense of the contribution he made, not only to Breton folklore in particular, but also to the study of folklore in general. This is not a note from myself, with the benefit of 125 years of hindsight, but from the obituary that appeared in Folklore upon his death in 1895. It is, of course, in the nature of obituaries to be generous, but nevertheless it gives a sense of the esteem in which he was held by his contemporaries by the end of his life.

It is almost impossible to over-estimate his services in rescuing the folklore of his nation from the bands of romancers and poets. Far be it from us to undervalue poetry and romance. They are frequently among the highest and most valuable efforts of the human intellect; but when they are deliberately palmed off on an unsuspecting public as the genuine products of the popular imagination, of which in reality they are only the bedizened and distorted presentment, it is time for all who have any regard for truth and any feeling for traditional poetry and humour to protect and to show, if they can, a more excellent way. Leaving to others the work of criticism, M. Luzel set an example to collectors of folklore in Brittany; and it is to his example that we owe the admirable work of M. Sébillot, M. Le Braz, and others who are proud to reckon themselves his disciples. His splendid collections of tales and songs from $L a$ Bretagne bretonnante are prized by all students of the subject, and will long 
keep his memory green and fresh as the pioneer of the Science of Tradition in Brittany.

(Folklore, Vol.6, No.3. September 1895, 311-12) 


\section{References}

Benjamin, Walter (1977) Illuminationen, Frankfurt-am-Main: Suhrkamp Verlag

de La Villemarqué, Theodore Hersart (1999) Barza-Breiz : Chants Populaires de la Bretagne. Paris : Editions du Layeur.

Delargy, James (1945) 'The Gaelic story-teller: with some notes on Gaelic folktales' (Sir John Rhys Memorial Lecture), Proceedings of the British Academy, 31, $177-221$

Gemie, Sharif (2007) Brittany 1750-1950: The Invisible Nation, Cardiff: University of Wales Press

Luzel, François-Marie (1887) Contes populaires de Basse-Bretagne (in 3 volumes), Paris: Maisonneuve et Charles Leclerc

Luzel, François-Marie (1995a) Contes Bretons, Rennes: Presses Universitaires de Rennes, Terre de Brume

Luzel, François-Marie (1995b) Contes du Boulanger, Rennes: Presses Universitaires de Rennes 
Morvan, Françoise (1999) Luzel, une biographie, Rennes: Presses Universitaires de Rennes

Müller, Max; Stone, J(ed.) (2002) The Essential Max Müller: On Language, Mythology and Religion. New York: Palgrave Macmillan US.

Zimmermann, Georges Denis (2001) The Irish Storyteller, Dublin: Four Courts Press 